Rhondalyn Peairs and Ellen Urton, with Donna Schenck-Hamlin

Movies on the Grass

\title{
Encouraging epiphanies through experiential learning at Kansas State University Libraries
}

ibraries continually seek effective ways to expand library service outside of traditional roles and beyond the "four walls." Accomplishing this goal often involves offering more resources and services online, or reinventing our spaces to be as inviting as public libraries, book retailers, or coffee shops. Academic libraries search for more dynamic and germane methods of appealing to their patrons by fostering engagement via information literacy, and creating programming that reflects both academic and personal interests. In this spirit, Kansas State University (KState) Libraries produced a new vision statement, "Expanding borders: Leading and learning with our community."

Movies on the Grass (MOG) is one example of how our academic

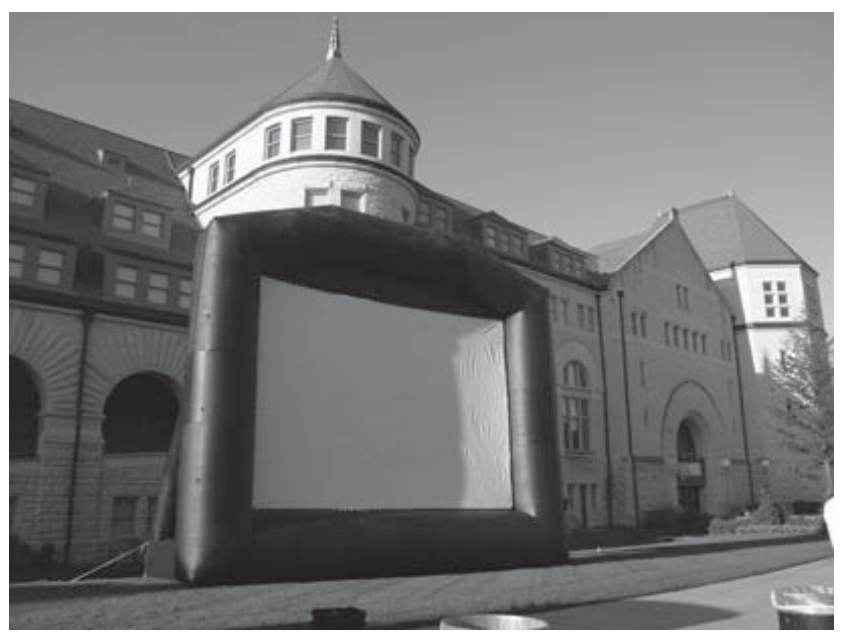

The Movies on the Grass (MOG) screen fully inflated in front of Hale Library.

library system successfully implements this vision. For two years, K-State Libraries traveled outdoors to host thought-provoking documentaries and feature films on a variety of contemporary issues. The series title, "Movies on the Grass," evokes both the casual spirit and physical location of this progressive program. A catalyst for discussion and reflection, the films tackle tough issues and questions on a large scale-both figuratively through global topics and literally through projection on a 26-foot inflatable screen against the backdrop of the library. This provocative film series is shown free-of-charge on Coffman Commons adjacent to Hale Library. Hale is the central branch of K-State University Libraries and is located in the heart of the Manhattan, Kansas, campus.

\section{Creating community}

A lack of local commercial choices for film entertainment left imaginations unsatisfied and intellects nearly starved in our university town of less than 50,000. Located more than an hour's drive from the nearest independent movie theater, an audience of local consumers sought international and independent documentary films. University librarians took the lead in the quest for alternative entertainment. In two years, the MOG series has exposed a public appetite for "movies with a conscience" that local venues have ignored. At the same time, MOG brings the K-State University Libraries

Rhondalyn Peairs is the director of the Dow Chemical Multicultural Resource Center, e-mail: rpeairs@gw. ksu.edu, Ellen Urton is visual arts librarian, e-mail: erurton@gw.ksu.edu, and Donna Schenck-Hamlin is assistant to the dean for grants and special projects, email: donnash@gw.ksu.edu, at Kansas State University ○ 2007 Rhondalyn Peairs and Ellen Urton, with Donna Schenck-Hamlin 
to the forefront in a fresh and unique way.

Originally created by librarians, faculty, and students in response to a dearth of diverse films, MOG is moving beyond its genesis as "alternative entertainment" towards becoming a platform for community awareness and engagement.

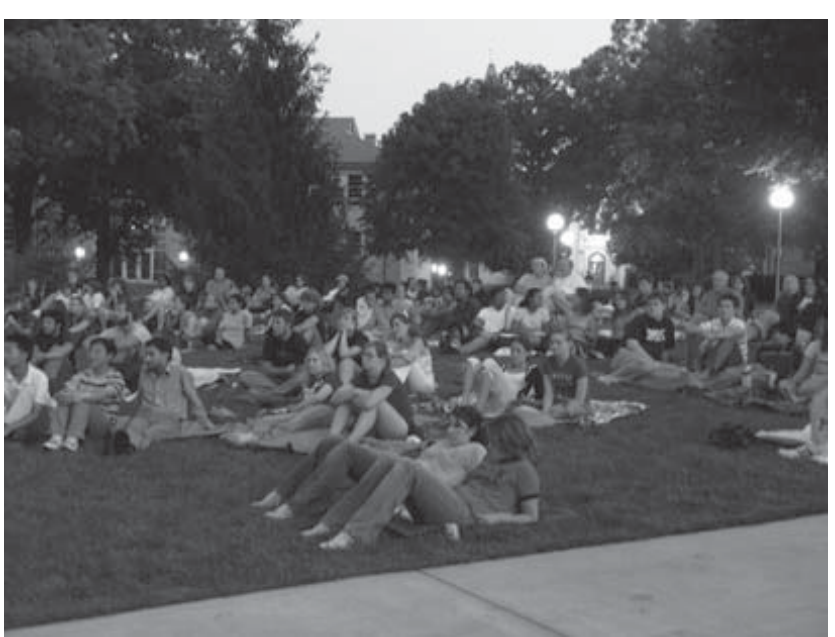

Movie goers enjoy a screening at Coffman Commons, in front of Hale Library.
The films are shown Sunday evenings during the fall semester, a time when new and returning students are more likely to explore the community and seek opportunities for involvement. Before each film, live music, information booths, and giveaways help to establish a relaxed atmosphere for viewing potentially provocative subject matter.

Immediately following the films, facilitators from K-State University's Institute for Civic Discourse and Democracy lead discussions in the library to explore the issues in a small group setting. In this way, the organizers seek to create a sense of community in the general audience that is often missing in popular venues, and to reinforce scholarly exploration and personal epiphany through discourse.

\section{A conversation between two librarians}

K-State Libraries' involvement in MOG grew out of a seemingly innocuous conversation between two K-State librarians: Rhondalyn Peairs, the director of the Dow Chemical Multicultural Resource Center (DowMRC), and Donna Schenck-Hamlin, the then current faculty advisor for Amnesty International, Group 254. During that conversation, Schenck-Hamlin shared the content of an informal springtime meeting. Meeting participants, including a student leader in the Progressive Coalition (a network of progressive student organizations), the director of the Women's Center, and a psychologist in University Clinical Services, considered subscribing to a traveling human rights film festival. The student, Megan Challender, formulated a fall activities grant proposal to the Student Governing Association, while Schenck-Hamlin began recruiting an action group to carry the project forward. Peairs became one such recruit when Schenck-Hamlin related this fledgling idea to her at the Hale Library loading dock. Peairs and the K-State Libraries Dean Lori Goetsch had been discussing various creative outreach ideas. Peairs and Schenck-Hamlin linked the two conversations and recruited other campus group representatives who showed an interest in "movies with a conscience" to develop a fall 2005 film festival.

In 2006, Ellen Urton, visual arts librarian, took on a more active role by becoming the third coordinator charged with supervising the graphic design interns, soliciting the participation of the Art Student Council, and photographing the series. As the first series coalesced, teamwork and funding became the two areas of primary importance.

Due to its fiscal and human resources, experience with program management, familiarity with public viewing rights, and ample indoor and outdoor space, Hale Library emerged as a natural leader in the implementation of MOG. Additionally, the library setting permitted a campus-wide ownership of the series that crossed multiple colleges and disciplines. In the first year, cross collaboration was feasible, due in large part to strong networking among like-minded organizations.

An alliance of progressive groups sponsored the 2005 series: Crossroads of the 
Ecumenical Christian Ministry, the Flint Hills Audubon Society, K-State Alliance for Peace and Justice, K-State Campaign for Nonviolence, K-State Women's Center, Manhattan Alliance for Peace and Justice, K-State's Office of Diversity and Dual Careers, Progressive Coalition, and Students for Environmental Action. Getting the series off the ground took mutual contributions of time and participation as well as collaborative funding.

\section{Sources of funding and selecting films}

Financing our free outdoor film series required the purchase or rental of films, acquisition of public viewing

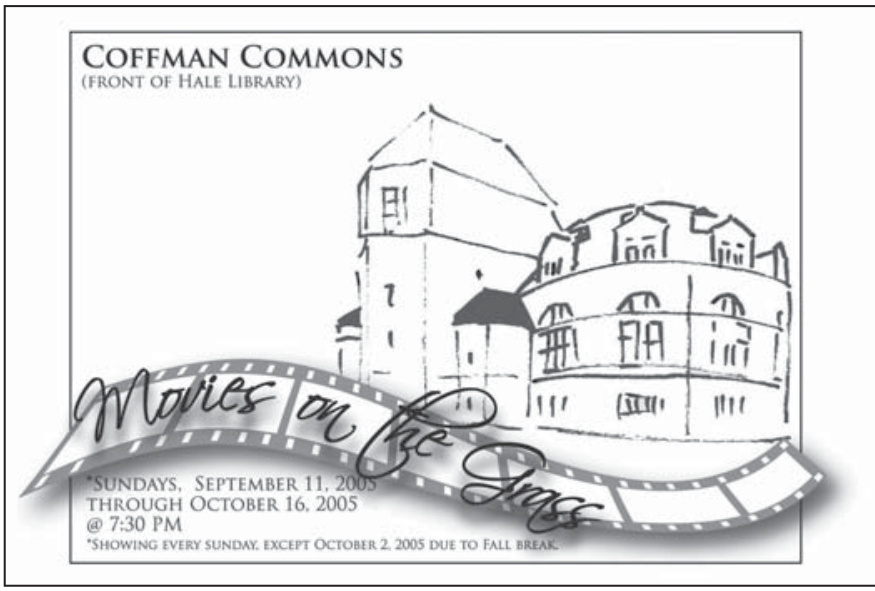

The MOG 2005 series handbill featuring an artist's rendering of Hale Library. rights, and rental of a 26-foot inflatable outdoor screen with appropriate projection equipment and personnel. In addition to the substantial support from the dean of libraries and the DowMRC endowment funds, grants from Amnesty International and the Student Governing Association and contributions from student and faculty groups augmented the libraries' fiscal contributions to the 2005 series. In 2006, additional support was obtained from community businesses recognizing the advertising opportunity.

The libraries seek to continue support without remaining the chief fiscal sponsor. They therefore seek deeper levels of financial commitment from collaborative partners by formalizing a board of directors, whose members will each take responsibility for specific functions within the series and identify new sources of funding.

\section{Selecting the films}

Each year, after securing financial support, the delicate task of film selection began. During the first months of film screening for the 2005
MOG series, some common themes surfaced. Emerging topics included a multiplicity of cultural and political perspectives, human rights and social justice, environmental sustainability, and international issues. Film selection was difficult due the competing opinions of MOG screeners and the need to balance between entertainment and awareness.

The quantity and quality of films and finding appropriate vendors for these movies presented a challenge. Res ourceful means of obtaining these films included renting them from a variety of sources, such as Human Rights Watch and SWANK, as well as using collection development funds to purchase films and public viewing rights.

Initially, to attract students through name recognition of a commercial movie, MOG began its 2005 series by showing Hotel Rwanda, a widely acclaimed feature film about the Rwandan genocide of 1994. The next film, Oil on Ice delved into the ramifications of opening the Arctic National Wildlife Refuge to oil exploration. Occupation Dreamland, the third selection, followed soldiers from the U.S. Army's 82nd airborne infantry in January 2004 as they carried out their duties in Al-Falluja, Iraq. The fourth viewing was a doublefeature pairing Mardi Gras: Made in China with Store Wars: When Wal-Mart Comes to Town. Both documentaries tackled consumerism, globalization, and labor issues. On the fifth night, another pair of documentaries, The Education of Shelby Knox and Stop the Traf$c k$, confronted the need for sex education and the horrors of child exploitation.

Approximately 800 viewers attended the 2005 series, and an average of 15 persons participated in post-film discussions, the 
most successful and intense being a dialogue between citizens and soldiers about Occupation Dreamland.

In 2006, the audience size increased to approximately 1,100 attendees, with 75 participating in post-film discussions. Like the year before, the 2006 series began with a blockbuster feature film, North Country, which presented the workplace origins of important sexual harassment legislation in the United States. The second film, Born into Brothels, followed a group of children photographers who documented their existence in the red light district of Calcutta, India.

\section{End of Suburbia,} the third film, revealed the human impact of urban sprawl and oil dependency on the environment. The final film, Invisible Children, explored the impact of war in the Acholiland region of Northern Uganda, underscoring the

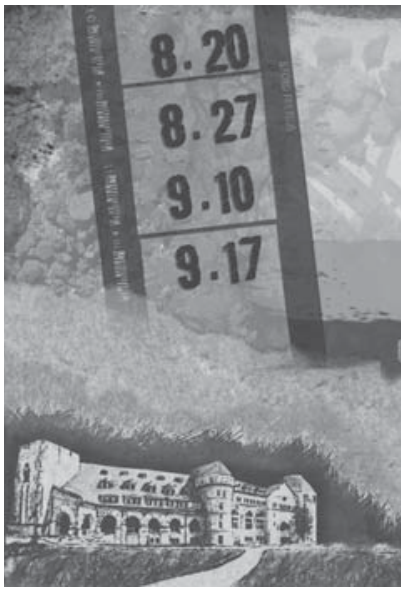

Student graphic interns designed this 2006 MOG series handbill. plight of that country's youth. Echoing an earlier theme set by Born into Brothels, Invisible Children also chronicles the use of art by children to deal with traumatic situations. In Born into Brothels, children learned to use photography to make sense of their world, while in Invisible Children, adolescents used their drawings to cope with the horrors they witnessed at the hands of the Lord's Resistance Army.

\section{Getting the word out}

In its second year, advertising the series became a greater priority as MOG organizers worked to build on their success.

In 2005, series promotion (though limited) was anchored by a strong design created by Ilia Leathers, using an artist's sketch of Hale Library. To market the 2006 series, MOG employed two student graphic interns, Caroline
Worthing and Matthew Jarmer, who collaborated to develop an earthy design scheme, which included banners, posters, handbills, and giveaways. Their designs incorporated universal visual elements such as grass, dirt, and rocks reflecting the gritty spirit of the chosen films. In addition, images of Hale Library are prominent in series publicity and on all promotional materials solidifying its centrality to the event.

What sets MOG apart from standard film viewing has been the engagement of community groups in promoting personal reflection and moving participants to act. In 2006, for

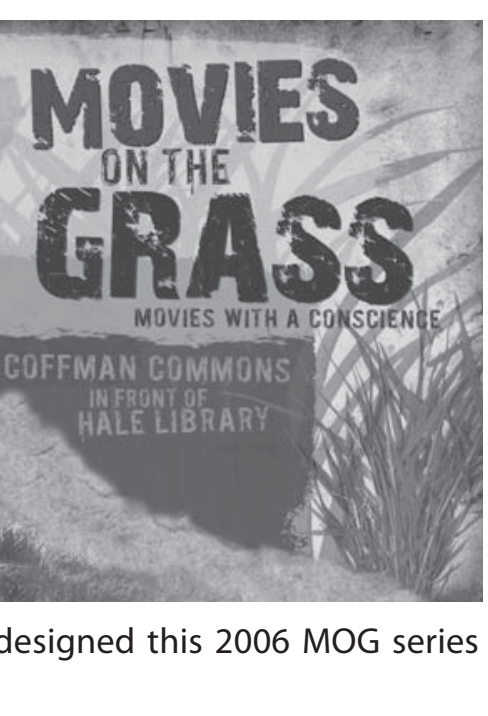

example, student designers of an all-solar house displayed their work in conjunction with the film End of Suburbia. Also, during Born into Brotbels, volunteers were recruited for the Court Appointed Special Advocates program, to support local children's need for advocacy. The most dramatic response came at the end of the 2006 series when audience members made donations to the non-profit organization that produced Invisible Children. These donations collected by MOG organizers went to the international movement, Invisible Children, to assist youth in Northern Uganda. By this time, many university faculty were recommending or requiring their students to attend one of the films, and some volunteered to lead the post-film discussion.

As the second season came to a close, MOG organizers received many requests and recommendations for the upcoming 2007 series, underscoring the community desire to continue this type of programming. Through the incorporation of film topics into the university curriculum, the libraries (continues on page 457) 
papers is the correspondence, which relates both to Mamet's professional work and to his personal life. Extensive correspondence from actor Joe Mantegna and performer Ricky Jay are included, as well as numerous letters from theater director Gregory Mosher; actors Patti LuPone, Steve Martin, and Jude Law; British playwright Harold Pinter; and film director Mike Nichols.

\section{The Barbara Gittings and Kay Tobin}

Lahusen Gay History Papers and Photographs, a major archive of materials accumulated over decades by two pioneers in the long-term campaign for gay and lesbian civil rights, has been acquired by the New York Public Library. The materials were donated by Gittings-an activist, editor, and writer who died in February-and by her life partner, photojournalist and author Lahusen. Gittings' papers document her activism on behalf of lesbian and gay rights from her founding in 1958 of the east coast chapter of the Daughters of Bilitis (first national lesbian organization, established 1955) and the editorship of its publication, The Ladder, until shortly before her death. Gittings' writings, protests, and other efforts influenced the American Psychiatric Association's (APA) removal of homosexuality from the list of mental illnesses and the inclusion of books by and for gays in library collections. She received awards from both the APA and the ALA for her lifetime achievements. Lahusen's extensive photographic collection documents gay activism-from images of early pickets, portraits of lesbian women for covers of The Ladder, and photos chronicling gay activists and activities including protests, parades, and political

("MOG" continued from page 447)

experiential learning opportunities on campus. Taking the concept of "library as place" outdoors to create an alternative venue for social engagement and academic discourse successfully promoted our libraries to our patrons. K-State Libraries is proud to be the proving ground for this idea. Movies on the Grass may not save the world, but it's a start ... and it definitely gets academic campaigns through 2005. Included also are her files and oral histories used in the preparation of her book The Gay Crusaders (1972). In addition to their personal papers and photographs is their extensive research collection of gay and lesbian newspapers, magazines, newsletters, flyers, t-shirts, buttons, press clippings, and sound and video recordings from across the country and around the world.

The entire European Union (EU) depository collection from the Delegation of the European Commission to the United States has been received by the University of Pittsburgh. The delegation decided to divest itself of this library and issued a Request for Proposals, and the University of Pittsburgh submitted the winning bid. The Delegation library was founded soon after the formation of the European Coal and Steel and Community (1951), which was the founding institution of what is now known as EU. The library includes the most extensive collection of public European Community/EU documents and publications in North America, including many items not received by the 56 other North American depository libraries (of which the University of Pittsburgh is one). The Delegation library contains a complete collection of the publications of the EU institutions and agencies, as well as partial collections of relevant private commercial publishers, international organizations, such as the Organization for Economic Cooperation and Development and Council of Europe, and European trade associations. Nearly all documents in the collection published since 1973 are in English; earlier documents are mostly in French. $\pi$

librarians out of the library and into their community.

\section{Acknowledgments}

Thanks to all who contributed so much to the success of Movies on the Grass: Susan Allen, Regina Beard, Megan Challender, Matthew Jarmer, David Jones, Doreen Lambert, Ilia Leathers, Gerry Snyder, Caroline Worthing, and Patricia Zapattini. z 